\title{
The New Face of Digital Books in Genetic Learning: A Preliminary Development Study for Students' Critical Thinking
}

\author{
https://doi.org/10.3991/ijet.v15i10.14321 \\ Riyanto \\ Universitas Negeri Malang, Malang, Indonesia \\ IKIP Budi Utomo Malang, Malang, Indonesia \\ Mohamad Amin ${ }^{(凶)}$, Hadi Suwono, Umie Lestari \\ Universitas Negeri Malang, Malang, Indonesia \\ mohamad.amin. fmipa@um.ac.id
}

\begin{abstract}
The development of new teaching and learning material can help students to prepare the new 21 st century relevant skills. One of the new teaching and learning materials was the interactive digital e-book named flipbook that became one solution in genetics learning. This study aims to develop the preliminary interactive genetics flipbook design based Aurora 3D Animation Maker and Anchored Instruction learning models in Protein Synthesis material. This preliminary study was conducted at the Biology Education Study Program, IKIP Budi Utomo Malang, Indonesia. The method used is the Thiagarajan development model. The results showed that the interactive genetics flipbook based Aurora 3D Animation Maker and Anchored Instruction learning models were feasible to use in a genetic subject, especially to enhance students' critical thinking at the university level.
\end{abstract}

Keywords-E-book, interactive, flipbook, genetic

\section{Introduction}

In the era of Industrial 4.0, a term representing the fourth industrial revolution, also known as the digital revolution. This period was characterized by automation in all types of tasks, artificial intelligence in all areas of life, robots, and endless possibilities that open up new technological opportunities [1],[2]. Accelerated the improvement of science was highly supported by the use of digital technology, commonly called the Information Super Highway [3]. The Industrial Revolution brings impact on the various joints of human life, including the world of education and learning. Education was currently in the knowledge age, where the acceleration of knowledge enhancement was very remarkable [4],[5]. Learning should also equip students with practical skills in terms of the use of technology that they will face in future work [6],[7]. The acceleration of knowledge was strongly supported by the use of digital technology. Consequently, the use of appropriate technology could improve learning quality [8]. Higher students 
needed competence in technology using, one of the important ones was critical thinking skill [9]. This skill would help students to be ready in higher education and build a career [10]. Critical thinking skill was one of the specific achievement in the education field in Indonesia today. The evaluation of students' critical thinking skill measured from their product to analyze, evaluate, compare, synthesize, and describe an existing problem or issue [11].

Biology was one of the subjects that need the development of technology, especially in the field of biology of molecular and genetics [12]-[14]. Thus, the molecular biology material received major attention from an educational study in the field of biology [12]. DNA and RNA were the basic materials studied in Molecular Biology and genetics subjects. The existence of this material plays an important role as the basis for understanding protein synthesis in the cells of living things. However, until now, Protein Synthesis material considered as one of the difficult materials and hard to understand for higher students, that because some reason, the internal and external factors. Internal factors included the lack of skill to think abstractly, and the lack of students' critical thinking skills. The external factor can be in the form of teaching methods and the learning environment.

Based on the learning student's analysis conducted on 59 Biology education students in IKIP Budi Utomo Malang (IBUM) known that the teaching material has become one of the external learning barriers in the percentage of $85 \%$. This showed that the application of appropriate teaching material still lacks in motivating students to think critically and improve student learning achievement. Therefore, to help students achieved critical thinking skills are needed an appropriate and flexible learning material that can be applied in all subjects, including biology. Consequently, determined the appropriate learning material to improve students' critical thinking skills becomes an interesting challenge for lecturer in the university [15].

Learning digital class is needed with the use of appropriate technology [16]. This would enable students to use the internet to exchange information and assess the truth of sources as material to respond to existing issues or problems. The technology designed according to the student needs would contribute to solving the learning problems. One technology that expected could solve the learning problems was an interactive flipbook based Aurora animation 3D maker application. The model used was an anchored instruction learning model. Anchored Instruction was the learning model that focuses on technology as classroom teaching material. Anchored Instruction was developed by The Cognition and Technology Group at Vanderbilt University, led by John Bransford [17]. Anchored Instruction helped students understand the usefulness of concepts by creating video scenarios that involved contextual objects [18], and using multimedia and video for learning became better [19]. Anchored Instruction learning strategies combined with interactive visual teaching materials [20] would help students obtain a lot of information and remember more ideas [12], [21], [22]. The technology that can be used in Anchored Instruction was Aurora 3D Animation Maker. Aurora 3D Animation Maker was an application to create text and logo with 3D effects that suitable for developing interactive teaching materials [23] in the experimental class produced better cognitive values compared to the control class [24]. The media of Aurora 3D 
Presentation was in a very good category because it could increase the student learning activities. Furthermore, the learning process becomes more effective and efficient [25].

Based on the explanation above, the researchers interested in developing flipbook materials based on the Aurora 3D Animation marker and Anchored Instruction to enhance students' critical thinking skills. Moreover, in Flipbook media, students involved in discussions in the digital classes. This media will help students to deliver information in the combination of text, graphics, sound, video, and animation. Consequently, the learning process becomes innovative and enjoyable for students. Therefore, the research and development study in this study has some objectives includes 1) to develop teaching materials based on Aurora 3D Animation Maker-based Flipbook and Anchored Instruction models in Protein Synthesis material for biology education students in IBUM; 2) to find out the feasibility level of Flipbook based on Aurora 3D Animation Maker and the Anchored Instruction model on protein synthesis material; and 3) to produce an interactive and innovative Flipbook based on Aurora 3D Animation Maker and the Anchored Instruction model that can improve the critical thinking skills of biology education students in IBUM.

\section{$2 \quad$ Method}

This study was a development study to produce the genetic teaching material based on Aurora 3D Animation Maker and Anchored Instruction learning model. The development of teaching materials used the Research and Development (R\&D) 4D model, according to Thiagarajan, which consists of four steps, namely Define, Design, Development, and Disseminate [26]. This study is preliminary, so researchers only report the development Phase to the Development Phase. The study starts from the Define Phase, namely the identification of material concepts that will be included in the Flipbook Teaching Material based on Aurora Animation 3D Maker. Then in the Design Phase, the design and manufacture of Flipbook based on Aurora 3D Animation Maker are carried out. After the Flipbook Aurora 3D Maker-based teaching materials have been designed and created, a development phase is carried out, namely product validation by experts and product trials in the learning process. Finally, it can be stated that the product is valid and practical and can be continued to the product dissemination Phase.

\subsection{Participants}

Small scale test was conducted in IBUM, Indonesia. In this limited trial, 59 students were taken randomly as the subjects of the trial. The students were given a draft of the teaching material for learning.

\subsection{Data Collection Tool}

The instrument of media validation sheet was in the form of a media validation questionnaire that contains some aspects of format, material, language, attractiveness, and there were also comments, suggestions, and conclusions. The questionnaire adopted 
from Adkhar that consists of 16 questions [27]. This instrument used to obtain data on the validator's assessment and opinion of teaching materials that compiled, so that become guidelines and references in revising teaching materials. Data obtained from the media validation questionnaire were qualitative and quantitative data. The material validation questionnaire. Instruments for material experts reviewed based on aspects of learning and material aspects.

\subsection{Data analysis technique}

The data analysis technique used in this study was a descriptive analysis technique performed using descriptive statistics. The data analysis techniques used were qualitative and quantitative. The qualitative analysis used to describe lecturer validation suggestions and documentation notes when implemented. The data were analyzed descriptively qualitatively, some suggestions used to improve the product at the revision stage while the documentation notes described to determine the usefulness of the product. Quantitative analysis used to describe the feasibility of the product based on the assessment of material experts, media experts, and language experts. Also, the quantitative analysis also used to describe the instructional impact of the use of teaching materials. The technique used to analyze the data of the validation results of teaching and learning materials was to use validator uses the number of criteria scores from the Likert scale results $(1=$ very not good, $2=$ not good, $3=$ good, $4=$ very good $)$ [28]. After obtaining the criteria score, the next step was to calculate the total score obtained by collecting the total validator's answers for each statement item. After the total score obtained from the data collection, the percentage of validator perception can be calculated.

\section{$3 \quad$ Result and Discussion}

Aurora 3D Animation Maker-based Flipbook development process refers to the research and development Phase results were explained as follows:

\subsection{Define phase}

Based on preliminary studies that have been carried out at IBUM, researchers found the problems and weaknesses of students in understanding bioprocess materials, especially protein synthesis. This due to internal and external factors. One internal factor was weak of students' critical thinking skills in learning protein synthesis material. While external factors were the lack of teaching materials, use in teaching and learning activities so that students have difficulty in understanding abstract material and linking it to real life. This causes students difficulties because students have to memorize theories without understanding concepts. In addition, learning becomes less optimal and makes students' critical thinking skills less developed.

The human resources at IBUM considered being very qualified because the majority of lecturer still young and fresh graduates so had the good skill to operate gadgets. The skill of human resources in terms of IT also supported by the existence of local network 
paperless facilities developed by the university. Supporting infrastructure for teaching and learning activities available in each room includes PCs/Laptops, active speakers, LCDs, and wi-fi connections. Starting with the identification of the problem above, appropriate teaching and learning materials needed to be able to convey the material in a practical and clear manner. The appropriate material to meet these needs was the $\mathrm{Au}-$ rora 3D Animation Maker-based Flipbook. The development of learning animation videos can help the learning process expected to make it easier for students to understand the concept of the material.

The student analysis phase included the analysis of students' understanding abilities. Based on unstructured observations and interviews conducted by researchers, it was found that students still had difficulty in understanding the concepts that link theory with real life. Most students appear to be less active when attending class because students do not like theoretical material. Furthermore, these conditions caused the students' critical thinking skills poorly developed. With these considerations, the researcher developed a teaching material to help students get a deeper understanding.

The researcher analyzes the task completion to determine the contents of the learning unit at the task analysis Phase. In this analysis obtained boundaries of the material that will be included and used in learning materials. Based on this analysis, the tasks in the learning process, as followed: describe nucleic acids, describe the function of proteins in the body, describe protein synthesis, describe transcriptions, describe the translation, and analyzing differences in transcription and translation.

The concept analysis phase included an analysis of the Biology learning material of protein synthesis material and curriculum determination. The curriculum used at the IBUM was the higher education curriculum. Based on these two analyzes, an outline of the material will be produced that presented in the development of teaching materials. At this stage, the researchers formulated the results of the task analysis and concept analysis above to be the goal of achieving learning outcomes. The details of the learning objectives were as follows: 1) Students could describe nucleic acids; 2) Students could describe the function of the protein in the body; 3) Students could describe protein synthesis; 4) Students could describe transcription; 5) Students could describe translations; 6) Students were able to analyze differences in transcription and translation

\subsection{Design phase}

The next phase was the design the teaching and learning materials which described in detail as follows:

The first stage in the design was collecting and adjusting the reference material used in the Flipbook. The material used refers to the IBUM Genetics module [29] and the book exploring the world of Biology XII [30]. In addition, researchers also refer to books that relevant to the material of protein synthesis, e-books, e-journals, and the internet. The format of teaching materials compiled by researchers was the Kvisoft Flipbook Maker Pro and Aurora 3D Animation Maker software.

The design of teaching materials adjusted to the results of the analysis of concepts and tasks that have been carried out. In addition, the selected teaching materials must be adjusted to the characteristics of students and existing facilities in the university. The 
teaching material divided into two stages, namely the stage of making learning animation videos using Aurora 3D Animation Maker and the stage of making Flipbook referred to the syntax of Anchored Instruction using Kvisoft Flipbook Maker Pro.

The production process was the final stage in making an animation-based Flipbook after the Flipbook editing stage complete. The production process with exporting Flipbook files to Html, exe, and swf formats. The purpose of the export in various formats was to make it easy for users to operate an animated video based Flipbook in accordance with their device compatibility. The product developed in this study development was the Flipbook learning media based on Aurora 3D Animation Maker and Anchored Instruction. The product developed was as follows: Development of teaching materials using the Kvisoft Flipbook Maker Pro 4.2.2 application and Aurora 3D Animation Maker18.03. The output of protein synthesis material on Aurora 3D Animation Makerbased flipbook teaching material in the form of Transcription Process, mRNA Modification, Amino Acid codons, and Translations.

Fig 2 shows a cover page that appears automatically when a Flipbook is open. On this page, there were two layers; the first layer was the Flipbook cover layer, while the second layer contains the Flipbook background in the form of a DNA image. At the bottom of each page, there were Flipbook control and navigation buttons for easy use.

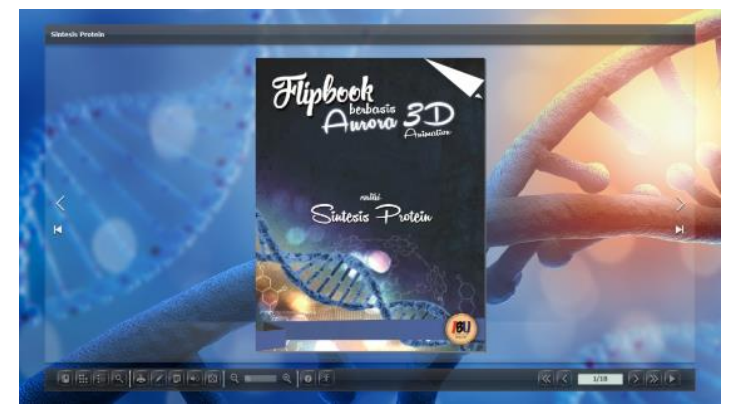

Fig. 1. Flipbook Cover

The usage pointer page intended to help users who don't have experience using Flipbook. The instructions page also explained the layout and functions of the digital buttons found in the Flipbook. The existence of this user guide page could facilitate the use of Flipbook based on Aurora 3D Animation Maker. The competence page contains four components core competencies, basic competencies, competency achievement index competencies, and learning objectives. The competence page aligned with the concept of map page so that students will more easily focus on the scope of the material they learned (see Fig 2). Meanwhile, in Fig 3, the problems were delivered in the form of video as an anchor in learning process, in order to trigger students' critical thinking. Besides, the material page contains Protein Synthesis topic in form of animation that was previously created using the Aurora 3D Animation Maker application. The video presented contains problems (Anchor), animated video of the transcription process, mRNA modification, and translation process. At the end of the material page, there was a conclusion page that contained the main and core material of protein synthesis. 

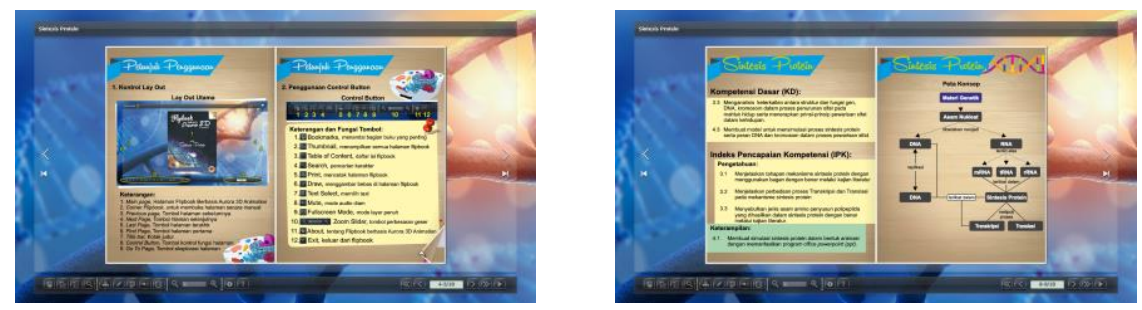

Fig. 2. The Guideline Page and Concept Map
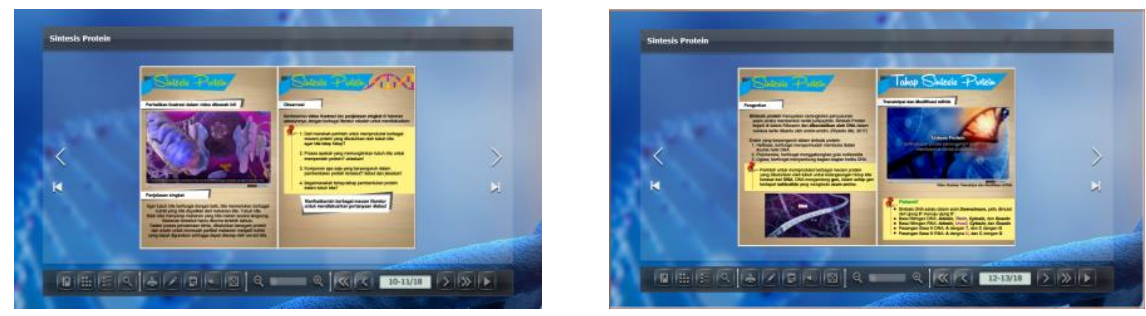

Fig. 3. Problems in video format and Material Pages with Anchor Videos Aurora 3D Animation Maker
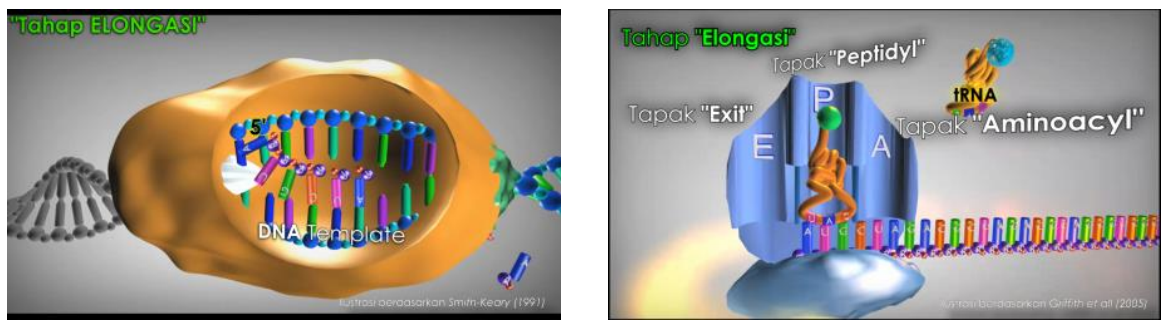

Fig. 4. Elongation Transcription Stage Animation Video

The problems in the form of video (anchor) (see Figure 3) were used to trigger students' critical thinking. In this case, the video presented story contained problems. The Flipbook provided some questions demanding critical thinking skill. This skill is needed to solve learning problems, in order to develop students' competence. In case of the material presented in the Flipbooks (see Figure 4), the Flipbook was also fully equipped by an animated video explaining the transcription process, mRNA modifications, and Translations. Videos played on the material pages according to the material described. 


\subsection{Development phase}

The development phase was an assessment by material experts, teaching materials, and language through a validation process. Before validating the material, teaching material, and language experts, the researcher first conducts the initial teaching material consultation with the supervisor. If the draft has been approved, then the teaching material then consulted with material experts, teaching materials, and language to obtain input then revision and validation. After obtaining the results of valid teaching materials that have been revised and assessed by media experts and material experts, further limited trials are conducted and can be continued in field trials.

There were two validations of this material validation. The 1 st validation wanted to determine the level of product feasibility in terms of material, while the 2nd validation wanted to revise the lack in the 1 st validation results. At this revision stage, the researcher got advice and input from material experts related to the concepts and materials in the Aurora 3D Animation Maker-based Flipbook.

Table 1. The Summary of the first Material Expert Validation

\begin{tabular}{|l|c|c|}
\hline \multicolumn{1}{|c|}{ Assessment Criteria } & \multicolumn{2}{c|}{ Validation } \\
\cline { 2 - 3 } & 1st Mean & 2nd Mean \\
\hline Completeness of material & 3.75 & 4 \\
\hline Material updates & 3.5 & 3.5 \\
\hline The material can improve students' scientific competence & 3.5 & 3.5 \\
\hline The material follows scientific systematics & 3.5 & 3.75 \\
\hline The material develops thinking skills and abilities & 3 & 4 \\
\hline Material stimulates students to know & 3.5 & 4 \\
\hline Total Mean & 3.5 & 3.8 \\
\hline
\end{tabular}

Based on Table 1, the 1st validation results by the material experts, the average score reached 3.5 with the very good achievement criteria. From the assessment conducted by material experts, there were several suggestions for the revision of the material. Suggestions and expert material input on the 1st validation used as a basis for improvement of the animation video. After the animation video material revised, then the video combined with Flipbook for the second stage of expert material validation. The 2nd validation results showed that the Flipbook evaluation based on Aurora 3D Animation Maker has improved by obtaining an average score of 3.8 and the criteria for achieving very good.

After making the revision, the revised animated video then inserted into the Flipbook. This animated video-based flipbook then validated again by media expert lecturers through second or overall validation. Media expert lecturers suggested improving the compatibility of learning programs because the programs in teaching and learning materials sometimes were not compatible to operate. The mean score from media experts is 3.8. Media expert lecturers gave a positive appreciation of the learning materials developed. According to the Flipbook-based media expert, Aurora 3D Animation Maker was very updated with the development of the era and technology and can be produced or commercialized as an alternative learning teaching material. Aurora 3D 
Animation Maker based flipbook with Anchored Instruction on protein synthesis material has been validated by expert media lecturers with very good criteria. Validation has done in two stages. The 1st validation to assess the feasibility of the Aurora 3D Animation Maker video animation. Whereas the 2 nd validation evaluated the animated video after revised and combined with Flipbook (see Table 2).

Table 2. The Summary of the first Media Expert Validation

\begin{tabular}{|l|c|c|}
\hline \multirow{2}{*}{\multicolumn{1}{|c|}{ Assessment Criteria }} & \multicolumn{2}{c|}{ Validation } \\
\cline { 2 - 3 } & 1st Mean & 2nd Mean \\
\hline Teaching material aspects & 3.86 & 3.86 \\
\hline Program display aspects & 3.1 & 3.78 \\
\hline Technical quality aspects, program effectiveness & 3.6 & 3.75 \\
\hline Total Mean & 3.5 & 3.8 \\
\hline
\end{tabular}

The results of the 1 st validation by the media expert on the animated video get a mean score of 3.5 with the criteria of achieving very good. Based on these achievement criteria, the Aurora 3D Animation Maker video animation included in the appropriate category for use. The conclusion of the results of the 1st validation by the media experts on the video animation was the Aurora 3D Animation Maker video animation is very valid and appropriate, but it would be better if some deficiencies corrected. There were some deficiencies that need to be fixed in the Aurora 3D Animation Maker video animation. Suggestions and input from media experts on the 1st validation then used as a basis for improving animated videos. After the animated video material revised, the video combined with Flipbook for the second stage of media expert validation. A summary of the results of the 2 nd validation by media experts. It can be concluded that the Flipbook evaluation based on Aurora 3D Animation Maker has improved by obtaining an average score of 3.8 and the criteria for achieving very good. With these results, it was concluded that the Flipbook could direct students' attention, understanding, and organizing the information.

According to the assessment of linguist lecturers, in general, it was good, but it would be better if the sound of accompaniment music played a little smaller volume so that the researcher's voice would be clearer. The use of accompaniment sounds during certain class hours, for example, during the daytime will affect student concentration. For that, the accompanying music volume needs to be considered so that students remain enthusiastic in learning activities. The mean score obtained from linguists is 3.6. Aurora 3D Animation Maker based flipbook with Anchored Instruction on protein synthesis material has been validated by linguist lecturers with very good criteria. Assessment aspects in the validation instrument of linguists divided into four aspects of language consisting of 10 questions. At the validation stage, the linguist gets input so that he pays attention to the volume and use of accompaniment music adapted to class hours. The results of the validation of the linguist summarized in Table 3. 
Paper-The New Face of Digital Books in Genetic Learning: A Preliminary Development Study...

Table 3. The Summary of Language Expert Validation

\begin{tabular}{|l|c|}
\hline \multicolumn{1}{|c|}{ Assessment Criteria } & Mean \\
\hline The use of appropriate language & 3 \\
\hline Terminology & 4 \\
\hline Language clarity & 4 \\
\hline Language suit skill & 3.3 \\
\hline Total Mean & 3.6 \\
\hline
\end{tabular}

Afterward, students filled out the questionnaires and gave their opinions about teaching material. Limited scale test aims to obtain the quality of Aurora 3D Animationbased Flipbook media. The assessment was a questionnaire distributed to 59 students. The response results then analyzed as a revised reference before the product used in the class. The results of a limited scale test by 59 students selected randomly so that it showed a response percentage of $92.5 \%$, included in the very good category. With this conclusion data, Flipbook based on Aurora 3D Animation Maker is feasible and valid to be used and can help students in the process of learning protein synthesis material.

Genetics was one of the biology subjects that students usually have difficulties in understanding. Consequently, it's needed a creative way to help students understand the material in the learning activities [31]. The Digital interactive book that suitable for the characteristics of genetic learning was the digital interactive flipbook. Digital interactive flipbook became popular digital books now with three-dimensional e-book technology, where the pages can be opened like reading a book on a monitor screen [32]. Digital interactive flipbook media has several advantages including, one of that it can present learning material in the form of words, sentences, and images that can be equipped with colors so that it attracts students' attention more. Furthermore, technology would make students involved in finding information, assessed the sources, and discussed to solve issues or problems. Using Aurora 3D Animation media in the experimental class produced better cognitive values compared to the control class. The Aurora 3D media Presentation was in a very good category because it can increase student learning activities. Consequently, the learning process becomes more effective and efficient [33]. Referring to some previous studies, it can be concluded that Aurora 3D teaching materials can improved student learning outcomes.

The media development also combined with the use of specific learning models. The model used was an anchored instruction learning model. AI was a learning model in which teachers strive to help students become active in learning that conditioned in interesting instructions and real problem solving, where students later see the video "anchor" and solve the problem in the video's [34]. Anchored instruction learning model designed based on a video-based format called "anchor" or "case" which provides a basis for exploration and collaboration in solving the problems. The material in the video depicts real life that can be explored at many levels. The video designed to enable teachers and students to connect knowledge with other lessons by exploring the environment from a different point of view [35]. Anchored instruction learning model almost identical to problem-based learning, just different in the material presented to "be explored and discussed not just read or seen" [36]. The essences of the anchored instruction learning model were "anchor" or placing instruction on a meaningful problem 
solving that matches the real context. The placement of the issue in accordance with the real context called a macro context because it involves a complex situation required students to formulate and solve interconnected problems between sub problems [21].

The use of multimedia and video in the Anchored instruction learning model proved the better effectiveness of learning [37]. Video technology, animation, computing were part of learning that provided a contextual learning experience [38]. Visual and audiovisual information in the anchored instruction learning model can make students easier to understand the concepts [39]. Furthermore, anchored instruction learning models showed more good in students' skills, especially in communication skills. An anchored instruction learning model that is using multimedia and video can improved students' collaboration and creativity so it can improve the learning effectiveness [40]. Anchored instruction learning model can enhance the students learning motivation and students' understanding [41]. Problem-based learning-based technology can give students challenging issues or problems that make learning more interesting and innovative.

Furthermore, interactive genetic flipbook based Aurora animated 3D maker with anchored instruction learning model can create a joyful learning environment so that students become more critical (especially when asked to solve the problem), more have effective communication skills, and more creative. Students expected became more active during the learning process with a variety of learning activities. This genetic flipbook arranged and presented in an integrated, systematic, and detailed way so that students can easily understand the material that considered as difficult for students. Anchored instruction learning models, when compared to other learning models, showed more positive students' attitudes towards their learning activities. Furthermore, students' knowledge showed better after the application of the anchored instruction learning model. An anchored instruction learning model that using multimedia and video showed better learning effectiveness [19]. Students who have been taught with learning media using anchored instruction have significantly different in problem-solving [42]. In the step of constructing and observing the situation, the video became support learning tools with variations forms, complex, and give contextual learning experiences [41],[43]. Visual information, as well as audiovisuals provided through the anchored instruction learning model, can make students easier to understand the learning concepts [44],[45].

The instruction anchored learning model that combined with visual teaching material has many interactivities. Consequently, the presentation can help students get a lot of information and can remember more ideas. Topics presented were relevant to daily life activities and presented in a story-based manner. Thus, that's learning environments allowed students to create better cognitive pathways [20]. The main advantages of instruction anchored learning model combined with visual teaching material were helped students identify and define their own problems, helped the development of various study skills, encouraged the learning point of views as a tool to achieve goals, applied the wide learning context, and helped students developed a cognitive framework that enables students assimilated the new learning [46]. Visual information, as well as audiovisuals, can make students easier to understand instructions of the learning concepts [44]. Multimedia in the anchored instruction learning model can improve students' motivation and understanding [41]. 
The study that relevant to this study conducted by the previous study assessed the impact of the anchored instruction learning model on student-teacher interactions. The researcher found that student-teacher interactions increased, and not only the teacher asked a higher question, but also, the students responded interchangeably [47]. It's also reported after using an anchored instruction learning model, students who normally lack an academic struggle and behavior becoming have better performance, attention, and participation. Furthermore, teachers reported having fewer classroom problems. The differences of the anchored Instruction learning model using video with the traditional instruction model in teaching problem solving found that student is more engaged in a positive attitude towards anchored instruction learning model [48]. Furthermore, the anchored instruction learning model proved to be more effective in the learning process.

\section{Conclusion}

The results showed that the validity by the material, media, and language experts was very good. The results of the limited scale test were in very good category criteria, with the percentage of $92.5 \%$. It concluded that preliminary development of the interactive genetics flipbook based Aurora 3D Animation Maker and Anchored Instruction learning models were feasible to use in a genetic subject, especially in the context of efforts to enhance students' critical thinking in the university. Some prescriptive actions may be proposed. The further study must consider developing the Flipbook based on Aurora 3D Animation Maker is another subject. The use of innovative teaching material helped students more motivated in the learning process due to the new digital era of education.

\section{$5 \quad$ References}

[1] M. F. Amir, N. Fediyanto, C. Chotimah, and H. E. Rudyanto, "Developing 3Dmetric Media Prototype through a Hypothetical Learning Trajector to Train Students Spatial Skill," J. od Adv Res. Dyn. Control Syst., vol. 10, no. 02 Special Issue, pp. 1537-1542, 2018. https ://doi.org/10.31227/osf.io/vmk45

[2] S. Zubaidah, "Biodiversitas: Lestarikan melalui Pembelajaran dan Pewarisan Pengetahuan Lokal," in Seminar Nasional Pendidikan Biologi dengan tema "Biodiversitas Kepulauan Maluku dan Pemanfaatannya bagi Pembelajaran Biologi di Era Revolusi Industri 4.0,” 2019. https://doi.org/10.33503/ebio.v4i01.441

[3] B. Gates, The Road Ahead. New York: Penguin Books, 1996.

[4] C. P. Wijaya and M. Muhardjito, "The diagnosis of senior high school class x mia b students misconceptions about hydrostatic pressure concept using three-tier," J. Pendidik. IPA Indones., vol. 5, no. 1, pp. 13-21, 2016.

[5] M. F. Amir, I. A. Mufarikhah, A. Wahyuni, Nasrun, and H. E. Rudyanto, "Developing 'Fort Defending' Game as a Learning Design for Mathematical Literacy Integrated to Primary School Curriculum in Indonesia," Elem. Educ. Online, vol. 18, no. 3, pp. 1081-1092, 2019. https://doi.org/10.17051/ilkonline.2019.610145 
[6] Masduki, Misnadin, and Z. Mufidah, "Writing scientific papers training for elementary school teachers in pademawu pamekasan," J. Community Dev. Soc., vol. 1, no. 2, pp. 5765, 2019. https://doi.org/10.25139/cds.v1i2.1840

[7] H. E. Rudyanto, Marsigit, M. N. Wangid, and S. Gembong, "The use of bring your own device-based learning to measure student algebraic thinking ability," Int. J. Emerg. Technol. Learn., vol. 14, no. 23, pp. 233-241, 2019. https://doi.org/10.3991/ijet.v14i23.11050

[8] H. Hart, L. E. Craine, and D. J. Hart, Kimia Organik Edisi Kesebelas. Jakarta: Erlangga, 2003.

[9] H. A. Alismail and P. McGuire, "21 st Century Standards and Curriculum: Current Research and Practice," J. Educ. Pract., vol. 6, no. 6, pp. 150-154, 2015.

[10] G. Ten Dam and M. Volman, "Critical Thinking as a Citizenship Competence: Teaching Strategies,” Learn. Instr., vol. 14, no. 4, pp. 359-379, 2004. https://doi.org/10.1016/j.learn instruc.2004.01.005

[11] J. E. Cottrell, G. A. Winer, and M. C. Smith, "Beliefs of children and adults about feeling stares of unseen others," Dev. Psychol., vol. 32, no. 1, pp. 50-61, 1996. https://doi.org/10. $\underline{1037 / 0012-1649.32 .1 .50}$

[12] S. Schuster, T. Pfeiffer, and D. A. Fell, "Is Maximization of Molar Yield in Metabolic Networks Favoured by Evolution?,” J. Theor. Biol., vol. 252, no. 3, pp. 497-504, 2008. https://doi.org/10.1016/j.jtbi.2007.12.008

[13] G. R. Parslow, "Commentary: The Khan academy and the day-night flipped classroom," Multimed. Biochem. Mol. Biol. Educ., vol. 40, no. 5, pp. 337-338, 2012. https://doi.org/ 10.1002/bmb.20642

[14] R. J. McDonough, A. S. Niven, and K. A. Havenstrite, "Congenital pulmonary airway malformation: a case report and review of the literature," Respir. Care, vol. 57, no. 2, pp. 302306, 2012. https://doi.org/10.4187/respcare.00727

[15] F. N. Tiruneh, K. Y. Chuang, and Y. C. Chuang, "Women's autonomy and maternal healthcare service utilization in Ethiopia," BMC Health Serv. Res., vol. 17, no. 1, p. 718, 2017. https://doi.org/10.1186/s12913-017-2670-9

[16] B. Pearlman, "Making 21st Century Schools: Creating Learner-Centered Schoolplaces/Workplaces for a New Culture of Students at Work," Educ. Technol., no. SeptemberOctober 2009, 2009.

[17] J. Bransford, "Cognitive Constructivism \& Social Constructivism: Anchored Instruction," Lincolnshire Community, 1990. .

[18] A. I. Sidik, H. Ashari, and H. A. Maftukhin, "Efektivitas Model Pembelajaran Anchored Instruction (AI) terhadap Penguasaan Konsep Fisika dan Hasil Belajar Siswa Kelas X SMA Muhammadiyah Purworejo Tahun Pelajaran 2015/2016," Radiasi, vol. 9, no. 2, pp. 59-64, 2016. https://doi.org/10.33394/j-lkf.v1i1.49

[19] M. Elçin, S. Turan, O. Odabaş1, and İ. Sayek, "Development and evaluation of the evidencebased medicine program in surgery: a spiral approach," Med. Educ. Online, vol. 19, no. April, 2014. https://doi.org/10.3402/meo.v19.24269

[20] Y. T. Chen, "A study of incorporating multimedia technology in PowerPoint on demand," New Educ. Rev., vol. 27, no. 1, pp. 172-183, 2012.

[21] J. D. Bransford, The Jasper Project: Lessons in curriculum, instruction, assessment, and professional development. Routledge, 2013. https://doi.org/10.4324/9781315045207

[22] C. N. Böttge, J. Hader, I. Kilen, S. W. Koch, and J. V. Moloney, "Influence of non-equilibrium carrier dynamics on pulse amplification in semiconductor gain media," Int. Soc. Opt. Photonics, vol. 9349, p. 934903, 2015. https://doi.org/10.1117/12.2080140

[23] H. T. Fikri, "Pengaruh Menuis Pengalaman Emosional dalam Terapi Ekspresif terhadap Emosi Marah pada Remaja,” J. Psikol. Humanit., vol. 9, no. 2, pp. 103-112, 2012. 
[24] G. Yeni, K. Syamsu, E. Mardliyati, and H. Muchtar, "Penentuan Teknologi Proses Pembuatan Gambir Murni dan Katekin Terstandar dari Gambir Asalan," J. Litbang Ind., vol. 7, no. 1, pp. 1-10, 2017. https://doi.org/10.24960/jli.v7i1.2846.1-10

[25] A. D. M. Suyitno, "Pengembangan Media Pembelajaran Berbasis Aurora 3D untuk Meningkatkan Akvitas Belajar Siswa Kelas XI Teknik Kendaraan Ringan SMK Negeri 2 Kebumen," J. Pendidik. Tek. Otomotif, vol. 8, no. 1, pp. 22-25, 2016. https://doi.org/10.24 832/jpnk.v20i1.123

[26] S. Thiagarajan, Instructional development for training teachers of exceptional children: A sourcebook. 1974.

[27] B. I. Adkhar, "Pengembangan Media Video Animasi Pembelajaran Berbasis Powtoon pada Kelas 2 Mata Pelajaran Ilmu Pengetahuan Alam Disd Labschool Unnes," Universitas Negeri Semarang, 2015. https://doi.org/10.21009/jrpk.011.01

[28] Sugiyono, Metode Penelitian Kuantitatif, kualitatif dan R \& D. Bandung: Alfabeta, 2013.

[29] J. Li and Y. E. Riyanto, "Category reporting in charitable giving: an experimental analysis," Econ. Inq., vol. 55, no. 1, pp. 397-408, 2017. https://doi.org/10.1111/ecin.12355

[30] P. Pujiyanto, "Evaluasi Pendidikan,” J. Mathlaul Fattah J. Pendidik. Dan Stud. Islam, vol. 9, no. 1, pp. 86-96, 2018.

[31] C. Roini, "Peningkatan Pemahaman Konsep Genetika Siswa SMA melalui Pembelajaran Peta Konsep pada Sekolah Berkategori Berbeda," J. Bionature, vol. 13, no. 1, pp. 25-30, 2012. https://doi.org/10.36294/jmp.v3i2.422

[32] S. Zubaidah, A. D. Corebima, and Mistianah, "Asesmen berpikir kritis terintegrasi tes essay. In Symbion: Symposium on Biology Education," in Symbion: Symposium on Biology Education, 2015, pp. 200-213.

[33] S. Mulyanto, Suyitno, R. A. Rachmanto, L. L. G. Hidayat, A. H. Wibowo, and S. Hadi, "Synthesis and characterization of natural red dye from Caesalpinia sappan linn," in AIP Conference Proceedings, 2016, vol. 1717, no. 1, p. 040032. https://doi.org/10.1063/1.4943 $\underline{475}$

[34] S. A. Barab and T. Duffy, "From practice fields to communities of practice," in Theoretical Foundations of Learning Environments, D. Jonassen and S. M. Land, Eds. Mahwah, NJ: Lawrence Erlbaum Associates, 2000, pp. 25-56.

[35] R. Cools and P. Rabinowitz, "Monomial cubature rules since 'Stroud': a compilation," J. Comput. Appl. Math., vol. 48, no. 3, pp. 309-326, 1993. https://doi.org/10.1016/0377-042 7(93)90027-9

[36] J. D. Bransford, A. L. Brown, and R. R. Cocking, How people learn: Brain, mind, experience, and school. Washington D.C: National Academy Press, 2000.

[37] M. Salam, D. N. A. Iskandar, D. H. A. Ibrahim, and M. S. Farooq, "Technology integration in service-learning pedagogy: A holistic framework," Telemat. Informatics, vol. 38, no. April, pp. 257-273, 2018. https://doi.org/10.1016/j.tele.2019.02.002

[38] K. Loreder, R. Pekrun, and J. Plass, "Emotional Fondations," in Handbook of Game-Based Learning, J. L. Plass, R. E. Mayer, and B. D. Homer, Eds. .

[39] T. J. Dunn and M. Kennedy, "Technology Enhanced Learning in higher education; motivations, engagement and academic achievement," Comput. Educ., vol. 137, no. August 2019, pp. 104-113, 2019. https://doi.org/10.1016/j.compedu.2019.04.004

[40] M. Elcin and B. Sezer, "An Exploratory Comparison of Traditional Classroom Instruction and Anchored Instruction with Secondary School Students: Turkish Experience," Eurasia J. Math. Sci. Technol. Educ., vol. 10, no. 6, pp. 523-530, 2014. https://doi.org/10.12973/ eurasia.2014.1171a 
[41] Y. Heo, "The Impact of Multimedia Anchored Instruction on the Motivation to Learn of Students with and Without Learning Disabilities Placed in Inclusive Language Art Classes," University of Texas of Austin, 2007.

[42] M. Lee, “Anchored Instruction in a Situated Learning Environment,” ERIC, 2002. .

[43] H. E. Rudyanto, A. Ghufron, and Hartono, "Use of integrated mobile application with realistic mathematics education: A study to develop elementary students' creative thinking ability,” Int. J. Interact. Mob. Technol., vol. 13, no. 10, pp. 19-27, 2019. https://doi.org/10. 3991/ijim.v13i10.11598

[44] C. Langone, C. Wissick, J. Langone, and G. Ross, "A Study of Graduates of a Technology Teacher Preparation Program," J. Technol. Teach. Educ., 1998.

[45] A. Al-amri, M. Osman, and A. Al Musawi, "The Effectiveness of a 3D-Virtual Reality Learning Environment (3D-VRLE) on the Omani Eighth Grade Students' Achievement and Motivation towards Physics Learning," Int. J. Emerg. Technol. Learn., vol. 15, no. 5, pp. 4-16, 2020. https://doi.org/10.3991/ijet.v15i05.11890

[46] D. Duncan, P. Kiefel, and I. Duncan, "Control of the spineless antennal enhancer: Direct repression of antennal target genes by Antennapedia," Dev. Biol., vol. 347, no. 1, pp. 8291, 2010. https://doi.org/10.1016/j.ydbio.2010.08.012

[47] C. W. Glaser, H. J. Rieth, C. K. Kinzer, L. K. Colburn, and J. Peter, "A Description of the Impact of Multimedia Anchored Instruction on Classroom Interactions," J. Spec. Educ. Technol., vol. 14, no. 2, pp. 27-43, 1999. https://doi.org/10.1177/016264349901400203

[48] H. Y. C. Shyu, "Using video-based anchored instruction to enhance learning: Taiwan's experience,” Br. J. Educ. Technol., vol. 31, no. 1, pp. 57-69, 2000. https://doi.org/10.1111/1 $\underline{467-8535.00135}$

\section{Authors}

Riyanto is a Doctoral Student of Biology Education, Universitas Negeri Malang, Indonesia. I am a lecturer in Biology IKIP Budi Utomo Malang. I was involved in various educational organizations, including HPBI, KOBI, and also as the chief editor of the Edubiotic journal: Journal of Education, Biology, and Applied after being a reviewer of the journal BIOEDUSCIENCE (Journal of Biology \& Science Education).

Mohamad Amin is a Professor of biotechnology at Department of Biology, University of Mathematics and Natural Sciences, Universitas Negeri Malang. He obtained his doctorate in the field of Molecular Genetics from the Martin Luther University of Halle-Wittenberg, Germany (2003). Besides serving as chairman of LPPM UM. In addition, also as chairman of the Malang Regency research council, In 2017 passed the World Class Professor program.

Hadi Suwono is a Professor of Biology Education Department of Biology, Faculty of Mathematics and Natural Sciences, Universitas Negeri Malang, Doctor of Biology Education, State University of Malang (2007). Besides serving as Dean of FMIPA Universitas Negeri Malang from 2018 until now. In 2016, she was chosen as the Coordinator of the Achievement Study Program of Universitas Negeri Malang.

Umie Lestari is a Doctor at Universitas Negeri Malang. Doctoral degree in Medical Science Program, Interest: Reproductive Biology, Universitas Brawijaya 
Paper - The New Face of Digital Books in Genetic Learning: A Preliminary Development Study...

(2008). Besides serving as chairman of the Molecular Biology Laboratory, Universitas Negeri Malang.

Article submitted 2020-02-23. Resubmitted 2020-03-27. Final acceptance 2020-03-27. Final version published as submitted by the authors. 